\title{
Kalkulačky environmentálních stop jídla ve vzdělávání a představení Nutriční stopy jako nástroje pro podporu udrži- telné spotřeby potravin
}

\section{Dana Kapitulčinová}

\section{Envigogika 12 (2) - Recenzované články/ Reviewed articles}

Publikováno / Published 22. 12. 2017

DOI: $10.14712 / 18023061.553$

\begin{abstract}
Abstrakt:
Studie se zabývá konceptem environmentálních stop a jejich veřejně dostupných kalkulaček (typicky webových aplikací) $v$ češtině $v$ ČR se specifickým zaměřením na spotřebu potravin. První část studie se zaměřuje na rešerši existujících kalkulaček, jejich charakteristiky, nejčastější nedostatky a využívání ve vzdělávání a osvětě z pohledu publikovaných recenzovaných studií. Druhá část článku pak představuje koncept Nutriční stopy jako nástroje pro podporu environmentálně udržitelného a zdravého stravování a s ním spojený vývoj nového vzdělávacího nástroje $v$ češtině, tzv. Kalkulačky Nutriční stopy. Na závěr je koncept Nutriční stopy diskutován $v$ kontextu dalších již běžnějších environmentálních stop a jejich kalkulaček (ekologické, uhlíkové, vodní stopy). $V$ neposlední řadě je představen potenciální navazující výzkum pro efektivní využití kalkulaček v EVVO a VUR.
\end{abstract}

\section{Klíčová slova:}

kalkulačka stopy jídla; uhlíková stopa; ekologická stopa; nutriční stopa; vzdělávání a osvěta; udržitelná spotřeba; potraviny; webová aplikace

\section{Abstract:}

The study deals with the concept of environmental footprints and their publicly available calculators (typically web applications) in Czech language in Czechia with a specific focus on food consumption. The first part of the study comprises a review of existing calculators, their characteristics, most common shortcomings, and their use in education and outreach from the point of view of published peer-reviewed studies. The second half of the article then introduces the concept of Nutritional Footprint as a tool for supporting environmentally sustainable and healthy eating and the development of a new educational tool in Czech language associated with it, a Nutritional Footprint Calculator. The Nutritional Footprint concept is then discussed in the context of other more commonly used environmental footprints and their calculators (ecological, carbon, water footprints). Last but not least, future potential research for effective use of calculators in environmental education (EE) and education for sustainable development (ESD) is outlined.

\section{Keywords:}

foodprint calculator; Carbon Footprint; Ecological Footprint; Nutrition Footprint; education; sustainable consumption; food; web application 


\section{Spotřeba potravin a (ne)udržitelnost}

Náš současný systém výroby a spotřeby potravin není z dlouhodobého hlediska udržitelný (IFPRI, 2016a). Problémy Ize nalézt od lokální po globální úroveň v podstatě ve všech oblastech definujících udržitelný rozvoj (Reisch et al., 2013) - rapidně celosvětově přibývá lidí trpících obezitou a ve stejnou dobu je každý devátý člověk na Zemi podvyživený (WHO, 2016; Gonzales Fischer \& Garnett, 2016); v mnoha produkčních systémech potravin existují také socio-ekonomické problémy - například špatné pracovní podmínky (Reisch et al., 2013) a z environmentálního pohledu je současná produkce potravin jedním z hlavních důvodů závažného poškozování životního prostředí, at' už se jedná o produkci skleníkových plynů přispívajících ke změně klimatu, změnu ve využití území s obrovskými dopady na ztrátu biodiverzity či spotřebu a znečištění vody sladké i mořské (Foley et al., 2011; Bailey \& Harper, 2015).

V zemích Evropské unie představuje současná spotřeba potravin jednu z hlavních environmentálních zátěží z celkové spotřeby domácností, která zároveň významně přesahuje hranice unijních států (European Environment Agency, 2014; Tukker et al., 2006). Například pro oblast skleníkových plynů vyprodukovaných v evropských domácnostech způsobují potraviny zhruba jednu čtvrtinu celkového dopadu domácností a z tohoto dopadu je za více než polovinu emisí skleníkových plynů zodpovědná spotřeba živočišných produktů, zejména masa a masných výrobků a také mléka a mléčných výrobků (Tukker et al., 2006; 2011).

Kvalita životního prostředí má zásadní vliv na kvalitu lidského života (EEA, 2015). Odborné studie předpokládají vynaložení značných ekonomických nákladů pro zachování ekosystémových služeb potřebných pro kvalitní život obyvatel, pokud bude společnost snižování environmentálních dopadů odkládat do budoucna (Stern, 2006). Každý člověk k těmto problémům do určité míry přispívá, nebot' každý člověk ovlivňuje dění kolem sebe a v dnešním globalizovaném světě to, co děláme a co konzumujeme, zásadně ovlivňuje nejen dění a životní prostředí v našem blízkém okolí (např. eutrofizaci vod, degradaci pưdy), ale často také na druhém konci světa (např. odlesňování v Jižní Americe a Jihovýchodní Asii, či výskyt extrémního počasí kvůli globální změně klimatu s dopadem v mnoha zemích světa).

\section{Výživa, životní prostředí a udržitelná strava}

Každý člověk a jeho volba stravování tedy zároveň představuje př́ležitost pro snížení výše zmíněných negativních dopadů. Je však nutné si uvědomit, že potraviny a jejich spotřeba jsou specifické oproti jiným produktům v tom, že jejich užívání nemůžeme ve velké míře omezit či úplně vyloučit. Uspokojení hladu je totiž základní fyziologickou potřebou, bez kterého není lidská existence možná.

Základním požadavkem při hledání udržitelného způsobu stravování je tedy na prvním místě zajištění adekvátní výživy, která zaručí dobrý zdravotní stav člověka. Zde je třeba myslet na veškeré formy neadekvátní výživy a to tedy nejen na podvýživu (způsobenou nedostatkem základních makroživin), ale také na skrytou podvýživu (způsobenou nedostatkem mikroživin) a nadvýživu (způsobenou nadměrnou konzumací makroživin při nedostatečném energetickém výdeji) (IFPRI, 2016b). Dále je pak zapotřebí nalézt určitou rovnováhu mezi zajištěním adekvátní zdravé výživy pro každého člověka a environmentálně i socioekonomicky udržitelnými aspekty výroby a spotřeby potravin. Organizace pro výživu a zemědělství (angl. FAO) proto v roce 2012 definovalo dlouhodobě udržitelné formy stravování, které zahrnují všechny zmíněné aspekty výše, jako tzv. udržitelnou stravu (angl. sustainable diet, FAO, 2012; podrobněji o konceptu v češtině viz Kapitulčinová, 2017). Výzkumníci z celého světa se nyní snaží tento koncept dále rozvinout a přijít se systémem hodnocení, 
který by indikoval, do jaké míry je určitá strava udržitelná (Clonan \& Holdsworth, 2012; Merrigan et al., 2015).

\section{Aktivity na úrovni mezinárodní a národní}

Mnohé mezinárodní instituce a organizace jsou si problémů s neudržitelností potravinových systémů a stravování vědomy a vyvíjí iniciativy, které by měly tento neblahý vývoj zvrátit. Organizace spojených národů (OSN) vyhlásila roky 2016-2025 Dekádou akcí k výživě (angl. Decade of Action on Nutrition), jejímž cílem je „ukončení hladu a vymýcení neadekvátní výživy při zajištění zdravějších a udržitelnějších forem stravování pro všechny lidi na světě". Na této iniciativě se podílí svými aktivitami několik odborných organizací OSN, např. FAO či Světová zdravotnická organizace (WHO, 2017). Program OSN pro životní prostředí (UNEP) pak vede desetiletý program na téma udržitelných potravinových systémů (angl. 10-Year Framework Programme on Sustainable Food Systems), který bude $v$ letech 2016-2025 podporovat iniciativy vedoucí k zajištění udržitelnějších praktik a spotřebitelského chování v oblasti potravin (UNEP, 2017).

Na úrovni Evropské unie je pozornost udržitelným potravinám věnována taktéž (European Commission, 2016) a existuje zde snaha o co největší informovanost spotřebitele. $V$ nedávné době např́klad proběhly tzv. Product Environmental Footprint (PEF) Pilots (20132016), které se snažily identifikovat pro různé typy produktů (včetně potravin) vhodné metody a dopadové kategorie $v$ oblasti životního prostředí a definovat vhodné značení, které by informovalo spotřebitele přímo na obalu o tom, jak environmentálně zatěžující ten který produkt je. Výstupy z tohoto výzkumu a pilotního testování by měly být projednány $v$ následujících několika měsících a finální závěry dostupné v lednu 2018 (European Commission, 2017). Environmentální zátěž pochopitelně není jediným aspektem udržitelnosti produktů, ale $v$ současnosti se této oblasti věnuje hodně pozornosti a $v$ budoucnu tedy můžeme pravděpodobně očekávat vznik nějakého typu značení environmentální zátěže na výrobcích prodávaných v EU a jeho zohlednění v legislativě.

Vedle přímého značení potravin se $v$ Evropě v posledních letech mnoho institucí snaží o celkovou osvětu a vzdělávání spotřebitelů. Jejich cílem je ovlivnit konzumenty a jejich spotřebitelské chování směrem $\mathrm{k}$ udržitelnějšímu (myšleno $v$ celé své šiři včetně socio-ekonomických aspektů). Hlavní roli zde hrají zejména neziskové organizace a případně také akademické instituce a privátní sektor. Z ČR je možné zmínit např́klad kampaň „Pěstuj planetu" (Ekumenická akademie, 2017), organizaci "Zachraň jídlo", či projekt „Menu pro změnu" (Glopolis, 2017) ${ }^{1}$. Tento článek pak ve své druhé části představuje jeden z hlavních výstupů projektu "Metodika stanovení Nutriční stopy pro vyjádření environmentálních a zdravotních aspektů spotřeby potravin $v$ ČR", který je realizovaný Univerzitou Karlovou v letech 2016-2017 a zaměřuje se mimo jiné na vývoj nového vzdělávacího nástroje pro podporu environmentálně udržitelného a zdravého stravování ${ }^{2}$.

\footnotetext{
${ }^{1}$ výčet není vyčerpávající, jedná se o príklady iniciativ a aktivních organizací z posledních let ${ }^{2}$ Dále uvažujeme pro účely tohoto článku pouze environmentální udržitelnost, ačkoli socio-ekonomické aspekty jsou $v$ reálu pochopitelně neodlučitelné
} 


\section{Spotřeba potravin a kalkulačky environmentálních stop}

Jedním z nástrojů osvěty a vzdělávání veřejnosti $v$ oblasti environmentální udržitelnosti jsou takzvané kalkulačky environmentálních stop ${ }^{3}$, které jsou poměrně časté $v$ zahraničí a do určité míry dostupné i v ČR. Tyto kalkulačky vznikly na základě indikátorů environmentální zátěže z produktů, aktivit jedince, domácností, měst či celých států (angl. "footprinting family of indicators") a jsou využívány od 90. let 20. století. Typicky se jedná o webové aplikace, které umožňují výpočet dopadu na životní prostředí v jedné kategorii např. ekologické stopy (výpočtem velikosti území potřebného pro zajištění zdrojů a likvidaci odpadů), uhlíkové stopy (výpočtem emisí skleníkových plynů), či vodní stopy (výpočtem objemu spotřeby vody) (Wackernagel et al., 2004; Hoekstra, 2009).

Hlavním cílem kalkulaček, které jsou zaměřené na jednotlivce a kterými se bude tento článek dále zabývat, je zprostředkování informací o míře dopadů různých oblastí lidského života na životní prostředí. Kalkulačky se zaměřují na oblasti života, ve kterých může jednotlivec své chování změnit a snižit tak svůj dosavadní negativní dopad na životní prostředí. Různé kalkulačky environmentálních stop jsou dostupné i $v$ ČR, ale $v$ české odborné literatuře zatím není dohledatelný žádný jejich přehled či výzkum, který by se využitím environmentálních stop ve vzdělávání a osvětě systematicky věnoval. Neexistuje tedy žádný přehled o tom, kdo kalkulačky vytváří (NNO, výzkumné instituce, privátní sektor?), jaké oblasti životního stylu zahrnují (doprava, bydlení, potraviny?) a jakým způsobem jsou prípadně využívány k environmentálnímu vzdělávání, výchově a osvětě, tj. EVVO, či širšímu pojetí ve formě vzdělávání pro udržitelný rozvoj, tj. VUR (zahrnutí do výukových programů?).

Vedle již existujících environmentálních stop a jejich kalkulaček pak v odborných studiích $v$ zahraničí vznikají také další nové koncepty, které jsou do určité míry zohledňovány také $v$ českém výzkumu a vzdělávání. Jedním takovým příkladem je rozvinutí nového konceptu "Nutriční stopy" v ČR a s ním spojené kalkulačky, která se specificky zaměřuje na environmentální zátěž z potravin ${ }^{4}$ a zároveň poskytuje informace o výživových hodnotách významných pro zdravé stravování.

\section{Cíle práce}

Na základě výše zmíněných poznatků si proto tato práce klade dva cíle:

1) Provést rešerši kalkulaček různých environmentálních stop dostupných $v$ češtině se specifickým přihlédnutím $\mathrm{k}$ jídlu (kdo vytvořil, jaké oblasti životního prostředí zahrnují, odkud berou data pro výpočty a jaké používají metodiky, jak jsou využívány k EVVO či VUR)

2) Představit koncept tzv. Nutriční stopy a s ním spojené nové webové kalkulačky a nastínit jejich potenciál ve vzdělávání pro podporu udržitelného stravování v ČR

\footnotetext{
3 "kalkulačky environmentálních stop" = souhrnný název pro všechny typy stop zaměřující se na dopady na životní prostředí (uhlíková, vodní, ekologická, nutriční).

${ }^{4} \mathrm{~V}$ tomto textu používám termíny "potraviny" a "jídlo" jako synonyma
} 


\section{Kalkulačky environmentálních stop jídla a výzkum v ČR}

Pro získání uceleného přehledu o existenci kalkulaček environmentálních stop v češtině a jejich využívání ve vzdělávání byla využita metoda triangulace datových zdrojů, která zahrnovala: 1) webové vyhledávání přes Google Search (pomocí klíčových slov "stopa kalkulačka”, „ekologická stopa kalkulačka”, "uhlíková stopa kalkulačka”, "vodní stopa kalkulačka”, "stopa člověka AND výuka” a „footprint AND education AND czech republic”); 2) vyhledávání relevantních článků v češtině v časopise Envigogika s využitím vyhledávače Google Scholar (pomocí klíčových slov „Envigogika stopa” a „Envigogika footprint”); a 3) vyhledávání článků v zahraniční odborné literatuře v databázi SCOPUS, Elsevier (pomocí klíčových slov "footprint calculator AND education", nejprve se všemi výsledky a poté s výsledy omezenými na pracoviště v ČR).

Všechna vyhledávání byla provedena či revidována (na základě předchozích vyhledávání v roce 2016 a 2017) v období 10.-11. 11. 2017. Vyhledávání bylo v prvním kroce pojato všeobecně pro zachycení všech existujících kalkulaček, podrobnější analýza výsledků vyhledávání pak byla ve druhém kroce zaměřena zejména na oblast potravin a na to, zda a jakým způsobem ji kalkulačky zohledňují.

\section{Kalkulačky zohledňující jídlo a jejich charakteristiky}

Výsledky vyhledávání zaměřeného na existenci webových kalkulaček v češtině zahrnující potraviny jsou prezentovány $v$ Tabulce 1 . Z přehledu je patrné, že $v$ současnosti je veřejně dostupných 7 kalkulaček, které nějakým zpưsobem zahrnují jídlo, z čehož 4 se zaměřují na uhlíkovou stopu (3 jsou kalkulačky osobní uhlíkové stopy a 1 kalkulačka uhlíkové stopy z dopravy jídla) a 3 kalkulačky se zaměřují na ekologickou stopu ${ }^{5}$,ve kterých jídlo zahrnují otázky týkající se osobní spotřeby, spotřeby jablek ze dvou různých zdrojů a spotřeby potravin ve školních jídelnách. Vodní stopa potravin zatím není v žádné kalkulačce $v$ češtině obsažena.

Poskytovatelé veřejně dostupných kalkulaček zmíněných v Tabulce 1 jsou ve většně prípadů z řad neziskových organizací (NNO) a to $v$ počtu $4 ;$ v jednom prípadě se jedná 0 spolupráci jedné NNO a jednoho akademického partnera; jedna kalkulačka je od akademické instituce a jedna od privátní firmy. Kalkulačky osobní uhlíkové stopy a ekologické stopy zahrnují výpočet pro dopad potravin na základě otázek vztahujících se nejčastěji ke: spotřebě masa; lokálnosti a sezónnosti potravin; a vlastní produkci.

Většina $z$ těchto kalkulaček však ( $v$ současně dostupné verzi) neposkytuje odkaz na konkrétní metodiky výpočtů, tj. informace o tom, jaké předpoklady a konkrétní čísla pro výpočty používají. Většina kalkulaček zmiňuje jen všeobecné informace o daném konceptu a neposkytují informace o konkrétních výpočetních vzorcích či zdrojích primárních dat. Výjimkami jsou uhlíková kalkulačka pro cesty jídla, která uvádí jako primární zdroj dat pro výpočty emisí z transportu jídla britskou instituci DEFRA (rok 2009) a také Kalkulátor uhlíkové stopy od Carbon Footprint Ltd., který obsahuje odkazy na informace o zdrojích dat a faktorů použitých ke konverzi hodnoty peněz utracených za potraviny na emise skleníkových plynů. Poslední kalkulačka, která uvádí primární zdroje dat, je „Ekostopa spotřeby" od Zeleného kruhu, ve které je pod sekcí „Ovoce” dostupné porovnání českého a novozélandského jablka s odkazem na soubor s daty použitými pro výpočty. Pro výpočet osobní ekologické stopy v kalulačce "Spočítej si ekostopu!”, také poskytnuté Zeleným kruhem, však informace

\footnotetext{
${ }^{5}$ pojem „ekologická stopa" je často krácen na slovo „ekostopa”, v tomto článku však uvádíme plný název „ekologická stopa” v souladu s anglickým názvem „Ecological Footprint"
} 
o primárních datech chybí. Zbývající veřejně dostupné kalkulačky tyto informace rovněž neposkytují.

Tabulka 1. Přehled českých kalkulaček environmentálních stop ve formě webových aplikací a zahrnujících ve výpočtech jídlo (veřejně dostupné k 11. 11. 2017)

\begin{tabular}{|c|c|c|c|c|c|}
\hline $\begin{array}{l}\text { Název } \\
\text { kalku- } \\
\text { lačky }\end{array}$ & $\begin{array}{l}\text { Datum } \\
\text { zveřej- } \\
\text { nění }\end{array}$ & $\begin{array}{l}\text { Kdo vy- } \\
\text { tvořil }\end{array}$ & $\begin{array}{l}\text { Typ } \\
\text { orga- } \\
\text { ni- } \\
\text { zace }\end{array}$ & $\begin{array}{l}\text { Co počítá a jak zo- } \\
\text { hledňuje jídlo }\end{array}$ & Odkaz \\
\hline $\begin{array}{l}\text { Kalku- } \\
\text { lačka uhlí- } \\
\text { kové } \\
\text { stopy do- } \\
\text { mácností }\end{array}$ & $\begin{array}{l}\text { Nedato- } \\
\text { váno } \\
\text { (projekt } \\
\text { GILDED } \\
\text { běžel v } \\
\text { letech } \\
\text { 2008- } \\
\text { 2012) }\end{array}$ & $\begin{array}{l}\text { Ekono- } \\
\text { mická Fa- } \\
\text { kulta JČU, } \\
\text { ČR (na } \\
\text { základě } \\
\text { projektu } \\
\text { GILDED) }\end{array}$ & $\begin{array}{l}\text { aka- } \\
\text { de- } \\
\text { mická }\end{array}$ & $\begin{array}{l}\text { Výpočet uhlíkové } \\
\text { stopy domácnosti v } 5 \\
\text { oblastech: vytápění, } \\
\text { spotřeba elektřiny, } \\
\text { automobilová, ve- } \\
\text { řejná a letecká do- } \\
\text { prava, a spotřeba } \\
\text { potravin; dopad z } \\
\text { potravin počítá na } \\
\text { základě } 3 \text { otázek } \\
\text { (spotřeba masa, se- } \\
\text { zónnost, vlastní pro- } \\
\text { dukce) }\end{array}$ & $\begin{array}{l}\text { http://test.scien- } \\
\text { cezoom.cz/hry-a- } \\
\text { kvizy/kalkulacka- } \\
\text { uhlikove-stopy-do- } \\
\text { macnosti }\end{array}$ \\
\hline $\begin{array}{l}\text { Kalkulátor } \\
\text { uhlíkové } \\
\text { stopy - } \\
\text { osobní }\end{array}$ & $\begin{array}{l}\text { Nedato- } \\
\text { váno }\end{array}$ & $\begin{array}{l}\text { Carbon } \\
\text { Footprint } \\
\text { Ltd., } \\
\text { Velká Bri- } \\
\text { tánie }\end{array}$ & $\begin{array}{l}\text { pri- } \\
\text { vátní }\end{array}$ & $\begin{array}{l}\text { Výpočet osobní uhlí- } \\
\text { kové stopy (s vidinou } \\
\text { následného "'offseto- } \\
\text { vání"); jídlo jen } \\
\text { velmi okrajově (na } \\
\text { základě vynalože-- } \\
\text { ných finančních vý- } \\
\text { dajů za potraviny a } \\
\text { nápoje) }\end{array}$ & $\begin{array}{l}\text { http://calcula- } \\
\text { tor.carbonfoot- } \\
\text { print.com/calcula- } \\
\text { tor.aspx?lang=cs }\end{array}$ \\
\hline $\begin{array}{l}\text { Uhlíková } \\
\text { kalkulačka } \\
\text { pro cesty } \\
\text { jídla }\end{array}$ & $\begin{array}{l}\text { Nedato- } \\
\text { váno } \\
\text { (pri- } \\
\text { mární } \\
\text { data z } \\
\text { r. 2009) }\end{array}$ & $\begin{array}{l}\text { Hnutí } \\
\text { DUHA }\end{array}$ & $\begin{array}{l}\text { nezis- } \\
\text { ková }\end{array}$ & $\begin{array}{l}\text { Výpočet uhlíkové } \\
\text { stopy z dopravy po- } \\
\text { travin s využitím rưz- } \\
\text { ných dopravních pro- } \\
\text { středků (lod', vlak, } \\
\text { nákladní auto, leta- } \\
\text { dlo); nezahrnuje } \\
\text { další části produkč- } \\
\text { ního řetězce }\end{array}$ & $\begin{array}{l}\frac{\text { http://hnuti- }}{\text { duha.cz/te- }} \\
\text { mata/uhlikova-kal- } \\
\underline{\text { kulacka-0 }}\end{array}$ \\
\hline $\begin{array}{l}\text { Kalku- } \\
\text { lačka uhlí- } \\
\text { kové } \\
\text { stopy-- } \\
\text { osobní }\end{array}$ & $\begin{array}{l}\text { Nedato- } \\
\text { váno } \\
\text { (beta } \\
\text { verze } \\
\text { kalku- } \\
\text { lačky) }\end{array}$ & $\begin{array}{l}\text { CI2 o.p.s } \\
\text { a FSS } \\
\text { Muni, ČR } \\
\text { (na zá- } \\
\text { kladě } \\
\text { existující } \\
\text { kalku- } \\
\text { lačky z } \\
\text { projektu }\end{array}$ & $\begin{array}{l}\text { nezis- } \\
\text { ková } \\
\text { a aka- } \\
\text { de- } \\
\text { mická }\end{array}$ & $\begin{array}{l}\text { Výpočet osobní uhlí- } \\
\text { kové stopy ve } 4 \text { ob- } \\
\text { lastech: bydlení, do- } \\
\text { prava, potraviny, } \\
\text { spotřeba; dopad z } \\
\text { potravin počíá na } \\
\text { základě } 7 \text { otázek } \\
\text { (spotřeba masa, } \\
\text { vlastní produkce, lo- }\end{array}$ & $\begin{array}{l}\text { http://www.uhliko- } \\
\text { vastopa.cz/ }\end{array}$ \\
\hline
\end{tabular}




\begin{tabular}{|c|c|c|c|c|c|}
\hline & & $\begin{array}{l}\text { Cally s } \\
\text { podporou } \\
\text { MŽP a } \\
\text { OAK } \\
\text { Foun- } \\
\text { dation) }\end{array}$ & & $\begin{array}{l}\text { kálnost a dovoz po- } \\
\text { travin) } \\
\text { (v současnosti je do- } \\
\text { stupná beta verze) }\end{array}$ & \\
\hline $\begin{array}{l}\text { Kalku- } \\
\text { lačka eko- } \\
\text { logické } \\
\text { stopy } \\
\text { (osobní) } \\
\text { "Spočítej } \\
\text { si ekos- } \\
\text { topu!" }\end{array}$ & $\begin{array}{l}\text { Nedato- } \\
\text { váno }\end{array}$ & $\begin{array}{l}\text { Zelený } \\
\text { kruh, o.s. } \\
\text { (iniciativa } \\
\text { Hra o } \\
\text { zemi) }\end{array}$ & $\begin{array}{l}\text { nezis- } \\
\text { ková }\end{array}$ & $\begin{array}{l}\text { Výpočet osobní eko- } \\
\text { logické stopy ve } 4 \\
\text { oblastech: bydlení, } \\
\text { potraviny, zboží a } \\
\text { služby, doprava; do- } \\
\text { pad z potravin počítá } \\
\text { na základě } 4 \text { otázek } \\
\text { (spotřeba živočiš- } \\
\text { ných produktů, prů- } \\
\text { myslově zpracova- } \\
\text { ných a balených po- } \\
\text { travin, lokálnosti a } \\
\text { dovozu ze zahraničí, } \\
\text { množství konzumo- } \\
\text { vaného jídla vzhle- } \\
\text { dem k vrstevníkům) }\end{array}$ & $\begin{array}{l}\text { http://www.hrao- } \\
\text { zemi.cz//files/eko- } \\
\text { stopa/ekos- } \\
\text { topa.php }\end{array}$ \\
\hline $\begin{array}{l}\text { Kalku- } \\
\text { lačka eko- } \\
\text { logické } \\
\text { stopy } \\
\text { (věcí a } \\
\text { aktivit) - } \\
\text { Ekostopa } \\
\text { spotřeby }\end{array}$ & $\begin{array}{l}\text { Nedato- } \\
\text { váno } \\
\text { (odkaz } \\
\text { na pri- } \\
\text { mární } \\
\text { data z } \\
\text { roku } \\
2007 \text { ) }\end{array}$ & $\begin{array}{l}\text { Zelený } \\
\text { kruh, o.s. } \\
\text { (iniciativa } \\
\text { Hra o } \\
\text { zemi) }\end{array}$ & $\begin{array}{l}\text { nezis- } \\
\text { ková }\end{array}$ & $\begin{array}{l}\text { Výpočet ekologické } \\
\text { stopy pro } 9 \text { vybra- } \\
\text { ných produktů a ak- } \\
\text { tivit; potraviny jsou } \\
\text { zahrnuté pod sekcí } \\
\text { "Ovoce”, kde je po- } \\
\text { rovnání českého ja- } \\
\text { blka a jablka u No- } \\
\text { vého Zélandu }\end{array}$ & $\begin{array}{l}\frac{\text { http://www.hrao- }}{\text { zemi.cz/swf/ekos- }} \\
\text { topa2.php }\end{array}$ \\
\hline $\begin{array}{l}\text { Ekostopa } \\
\text { školy - } \\
\text { kalkulátor } \\
\text { ekologické } \\
\text { stopy }\end{array}$ & $\begin{array}{l}10.5 . \\
2012\end{array}$ & $\begin{array}{l}\text { TIMUR, } \\
\text { o.s., ČR }\end{array}$ & $\begin{array}{l}\text { nezis- } \\
\text { ková }\end{array}$ & $\begin{array}{l}\text { Výpočet ekologické } \\
\text { stopy školy v } 9 \text { ob- } \\
\text { lastech provozu, } \\
\text { včetně školní jídelny; } \\
\text { dopad z potravin po- } \\
\text { čítá na základě } 9 \\
\text { otázek (spotřeba } \\
\text { masa, lokálnost, bio } \\
\text { potraviny, vlastní } \\
\text { produkce, komposto- } \\
\text { vání, průmyslově } \\
\text { zpracované suroviny) }\end{array}$ & $\begin{array}{l}\text { http://kalkula- } \\
\text { tor.ekostopa.cz/ }\end{array}$ \\
\hline
\end{tabular}




\section{Environmentální stopy ve vzdělávání a výzkumu}

Vyhledávání článků v české i zahraniční odborné literatuře ukázalo, že vzdělávání za pomoci kalkulaček environmentálních stop a výzkum $v$ této oblasti jsou $v$ ČR prozatím jen velmi sporadické. Tabulka 2 obsahuje nalezené relevantní články publikované v časopise Envigogika na toto téma.

Jediný článek, který autorka tohoto textu v časopise Envigogika nalezla a který se dosud věnoval využití environmentálních stop v praktické výuce, byl publikován v roce 2016 a zabýval se představením nové metodologie autora pro projektovou výuku, zaměřenou na realizaci adaptačních opatření na změnu klimatu v životě žáků vyšších ročníků ZŠ či studentů SŠ (Andres, 2016). Autor v něm shrnuje své zkušenosti z několika projektů na školách, které mimo jiné zahrnovaly ekologickou stopu, uhlíkovou stopu či vodní stopu a zmiňuje mimo jiné projekt EKOSTOPA od neziskové organizace TIMUR, o.s. Projekt s plným názvem "EKOSTOPA jako nástroj vzdělávání žáků základních a středních škol" probíhal v letech 2010 2013 s finanční podporou Ministerstva školství, mládeže a tělovýchovy v rámci Operačního programu Vzdělávání pro konkurenceschopnost z Evropského sociálního fondu ČR (viz stránky Ekostopy školy) a je jedním z nejnovějších a zřejmě také nejobsáhlejších projektů, které se dosud využití environmentálních stop ve výuce věnovaly. Je tak usuzováno na základě vyhledávání na internetu pomocí Google Search, viz metody uvedené v článku výše, ačkoli TIMUR realizoval i podobné menší projekty v předchozích letech, viz "Projekty” na stránkách Ekostopa školy. Žádné další články, které by se týkaly projektu EKOSTOPA či nějakého podobného projektu, však nebyly nalezeny.

Další dva relevantní články publikované v časopise Envigogika se na environmentální stopy a vzdělávání zaměřovaly $v$ obecnější rovině, která je však kontextuálně pro tento článek také neopomenutelná. Matějček a Bartoš (2012) zkoumali environmentální gramotnost učitelů (základních škol a gymnázií) a studentů učitelství (na PřF UK v Praze a PřF UJEP v Ústí nad Labem) formou otázek ohledně významu některých environmentálních termínů, včetně termínu "ekologická stopa”. Pouhá jedna třetina dotazovaných definovala termín vyhovujícím způsobem, zbylé dvě třetiny učitelů a studentů učitelství tento termín neznalo, či mu rozumělo v jiném významu. Znalost termínu se prokazatelně lišila dle aprobace jednotlivých respondentů, přičemž délka praxe (věku respondentů) neměla na environmentální gramotnost vliv. Dalším zajímavým zjištěním vzhledem k zaměření tohoto článku na potraviny ve vzdělávání bylo, že více než $40 \%$ dotazovaných odpovědělo, že konzumace hovězího masa nemá žádný dopad na životní prostředí.

Janoušková et al. (2017) pak environmentální stopy a vzdělávání zmiňují v souvislosti s hledáním vhodných indikátorů pro lepší uchopení udržitelného rozvoje ve vzdělávání a osvětě široké veřejnosti. Navrhují pět tematických oblastí - Lidé, Planeta, Prosperita, Mír a Partnerství - a v oblasti Planeta zmiňují právě tzv. "footprint family" indikátory, ze kterých pro širokou osvětu vybrali uhlíkovou stopu (případně zmiňují také možnost využití materiálové stopy či ekologické stopy).

Všechny zmíněné publikace se věnovaly environmentálním stopám v kontextu vzdělávání a osvěty na úrovni osobní stopy uživatele (žáka, studenta, veřejnosti). Nebyla nalezena žádná studie, která by se specificky v kontextu vzdělávání s využitím environmentálních stop zabývala potravinami (jak tomu je v případě tohoto článku). 
Tabulka 2. Přehled článků publikovaných $v$ časopise Envigogika zaměřující se na environmentální stopy ve vzdělávání všeobecně - tj. nejen na potraviny (veřejně dostupné $\mathrm{k} 11$. 11. 2017)

\begin{tabular}{|c|c|c|c|c|}
\hline Název článku & Autoři & $\begin{array}{l}\text { Rok } \\
\text { vydání }\end{array}$ & Popis a relevance & Odkaz \\
\hline $\begin{array}{l}\text { Environmentální gra- } \\
\text { motnost učitelů a } \\
\text { studentů učitelství }\end{array}$ & $\begin{array}{l}\text { Matějček, T.; } \\
\text { \& Bartoš, J. }\end{array}$ & 2012 & $\begin{array}{l}\text { Autoři zkoumali environ- } \\
\text { mentální gramotnost uči- } \\
\text { telů a studentů učitelství, } \\
\text { včetně znalosti definice } \\
\text { ekologické stopy či ná- } \\
\text { zoru na dopady na životní } \\
\text { prostředí ze spotřeby ho- } \\
\text { vězího masa (mimo ji- } \\
\text { ného). }\end{array}$ & $\begin{array}{l}\text { https://envigo- } \\
\text { gika.cuni.cz/in- } \\
\text { dex.php/Envigo- } \\
\text { gika/ar- } \\
\text { ticle/view/75 }\end{array}$ \\
\hline $\begin{array}{l}\text { Adaptace na změnu } \\
\text { klimatu ve školní } \\
\text { praxi }\end{array}$ & Andres, R. & 2016 & $\begin{array}{l}\text { Autor prezentuje meto- } \\
\text { diku projektové výuky za- } \\
\text { měřené na realizaci adap- } \\
\text { tačních opatření na } \\
\text { změnu klimatu v životě } \\
\text { žáků zŠ a studentů SŠ, } \\
\text { včetně zahnutí výpočtů } \\
\text { ekologické či uhlíkové } \\
\text { stopy. }\end{array}$ & $\begin{array}{l}\frac{\text { https://envigo- }}{\text { gika.cuni.cz/in- }} \\
\text { dex.php/Envigo- } \\
\text { gika/ar- } \\
\text { ticle/view/513 }\end{array}$ \\
\hline $\begin{array}{l}\text { Pět klíčových indiká- } \\
\text { torú udržitelného } \\
\text { rozvoje: Nástroj pro } \\
\text { vzdělávání a osvětu } \\
\text { veřejnosti }\end{array}$ & $\begin{array}{l}\text { Janoušková, } \\
\text { S.; Moldan, } \\
\text { B.; \& Hák, T. }\end{array}$ & 2017 & $\begin{array}{l}\text { Autoři revidují indikátory } \\
\text { vhodné pro lepší uchopení } \\
\text { udržitelného rozvoje ve } \\
\text { vzdělávání a osvětě ši- } \\
\text { roké veřejnosti, v oblasti } \\
\text { "Planeta" doporučují vyu- } \\
\text { žívat uhlíkovou stopu } \\
\text { (př́ipadně materiálovou či } \\
\text { ekologickou). }\end{array}$ & $\begin{array}{l}\text { https://www.en- } \\
\text { vigo- } \\
\text { gika.cuni.cz/in- } \\
\text { dex.php/Envigo- } \\
\text { gika/ar- } \\
\text { ticle/view/536 }\end{array}$ \\
\hline
\end{tabular}

\section{Diskuze ke kalkulačkám a výzkumu environmentálních stop (jídla) v České republice}

\section{Časté nedostatky kalkulaček a odborná doporučení}

Jedním z hlavních nedostatků veřejně dostupných kalkulaček environmentálních stop zahrnujících jídlo (viz Tabulka 1), které autorka tohoto textu identifikovala, je neposkytování informací o primárních datech či jejich zdrojích a konkrétním metodickém postupu jednotlivých výpočtů (včetně výpočetních vzorců) u velkého počtu zveřejněných kalkulaček. Uvedené nejsou ani informace o nejistotách, které jsou $s$ výpočty spojeny. Přesnost výpočtu (nejen) za oblast potravin tak může být z důvodu velké všeobecnosti otázek a výše zmíněných nedostatků přinejmenším diskutabilní.

Veřejně dostupné kalkulačky environmentálních stop by proto měly vždy obsahovat odkaz na informace, kde se $v$ prípadě zájmu uživatel dozví konkrétní zdroje dat (případně i 
konkrétní čísla, pokud mají autoři práva ke zveřejnění) a také podrobný metodický postup výpočtu výsledku. Vhodným doplněním by také mělo být nějaké alespoň hrubé zhodnocení nejistot $v$ jednotlivých výpočtech a celkovém výsledku. Dále by bylo vhodné uvádět také datum zveřejnění a datum poslední aktualizace každé kalkulačky, aby si uživatel dokázal představit, jak aktuální či zastaralá mohou data - a tudíž i výsledky - v dané kalkulačce být.

Nepřekvapivé je pak zjištění, že v současnosti neexistuje žádná kalkulačka v češtině, která by se zabývala specificky potravinami. Zatím totiž není takových kalkulaček větší počet ani v zahraničí (výjimkou je např. kalkulačka uhlíkové stopy pokrmů od Eaternity ve Švýcarsku či od Eat Low Carbon v USA), odkud k nám koncept environmentálních stop a kalkulaček přichází $v$ první řadě. Tato skutečnost je dána tím, že potravinový systém je velmi komplexní a jeden typ potraviny (např. rajče) je možno vyprodukovat a dostat ke konzumentovi mnoha různými způsoby (např. vypěstovat na poli $v$ ČR a dodat přes bedýnkový systém, či vyprodukovat ve Španělsku ve skleníku a dovézt do hypermarketu v ČR, či cokoli mezi tím). Dalším důvodem je blízká propojenost zemědělských systémů s přírodními ekosystémy a fakt, že některé dopady na životní prostředí jsou jen velmi těžko vyčíslitelné na 1 kg produktu (např. emise skleníkových plynů vyprodukovaných $v$ souvislosti s prodaným bochníkem chleba vyčíslit vědci umí, vyčíslení snižení biodiverzity při zakoupení stejného bochníku chleba však pro výzkumníky zůstává metodologickou výzvou). $Z$ tohoto důvodu je třeba brát výsledky výpočtů veškerých kalkulaček ( $a$ u jídla obzvlášt') spíše orientačně, než bezmezně věrit konkrétním číslům na desetinnou čárku. Upozornění na tento fakt by měly veřejně dostupné kalkulačky také obsahovat.

\section{Co Ize odvodit o výzkumu a vzdělávání na základě odborných studií?}

Na základě informací o tvůrcích kalkulaček environmentálních stop (Tabulka 1) se zdá být logické, že zatím $v$ této oblasti neprobíhá mnoho výzkumných aktivit, které by byly následně prezentovány $v$ odborných článcích $v$ češtině či angličtině. Průkopníky ve vytváření kalkulaček byly $v$ ČR neziskové organizace, mezi jejichž výstupy zpravidla nepatří akademické studie a $\mathrm{k}$ iniciaci či spolupráci na vývoji kalkulaček $\mathrm{z}$ r̆ad akademických partnerů dochází až v posledních letech (Tabulka 1).

$Z$ tohoto důvodu také zřejmě zatím ve větší míře chybí nějaké systematické zhodnocení zkušeností s kalkulačkami environmentálních stop ve vzdělávání a osvětě české společnosti (od žáků po veřejnost). Tyto zkušenosti totiž zcela jistě existují, nedostávají se však na stránky odborných časopisů. Z tohoto pohledu je škoda, že zkušenosti z projektů typu EKOSTOPA a dalších nebyly publikovány $v$ žádném dohledatelném odborném článku, ve kterém by byly shrnuty provedené aktivity, úskalí $i$ úspěchy projektu a došlo tak $\mathrm{k}$ přenosu poznatků $\mathrm{k}$ odborné veřejnosti. Tento stav však pochopitelně vyplývá $z$ charakteru práce neziskových organizací.

Z dostupných relevantních studií $\mathrm{k}$ environmentálním stopám publikovaných $\mathrm{v}$ časopise Envigogika se může čtenář $v$ současnosti dozvědět $v$ podstatě tři užitečné informace: 1) jakým způsobem je možné začlenit využití metodologie environmentálních stop do výuky žáků ZŠ a studentů SŠ; 2) jaká je relativní (ne)znalost pojmu ekologická stopa z řad učitelů a (ne)znalost dopadů různých aktivit člověka na životní prostředí (např. spotřeba hovězího masa); a 3) relativní (ne)vhodnost využívání konceptu uhlíkové stopy (či dalších environmentálních stop) při komunikaci ohledně udržitelného rozvoje $v$ širších souvislostech ve společnosti. Navíc nebyla nalezena žádná studie, která by hodnotila, zda a jaký efekt mělo využití kalkulaček na znalosti a kompetence uživatelů (žáci, studenti, veřejnost) a jejich př́padné změny ve spotřebitelském chování. 
Na základě těchto informací je pak možné se zamyslet nad možnými řešeními neuspokojivého stavu $v$ některých zmíněných oblastech - např. mylná domněnka velké části učitelů současných i budoucích o tom, že konzumace hovězího masa nemá dopad a životní prostředí, což silně kontrastuje se skutečností ilustrovanou v úvodní části tohoto článku. $\mathrm{A}$ $\checkmark$ neposlední řadě si ujasnit s tím spojené priority dalších žádoucích aktivit, včetně vzdělávání a výzkumu.

\section{Omezení použitých metod studie}

V této části článku je také nutné zmínit omezení spojená s použitou metodou triangulace datových zdrojů a s konkrétními postupy zvolenými pro vyhledávání informací a dat pro tuto přehledovou část studie. Prezentovány jsou pouze kalkulačky environmentálních stop a výzkumné aktivity, které byly nalezeny vyhledáváním na internetu dle výše zmíněné specifikace. Přehled a informace zde zmíněné tedy nemusí být vyčerpávající. Posouzení článku třemi nezávislými recenzenty by však mělo zajistit, že nebude opomenuta žádná informace, která by byla pro dané téma zcela zásadní.

\section{Představení Nutriční stopy jako nástroje pro podporu udržitelné spotřeby potravin}

Z analýzy veřejně dostupných kalkulaček environmentálních stop vyplývá, že existují veřejně dostupné výpočetní aplikace, které spotřebu potravin do určité míry zahrnují. $V$ současnosti však neexistuje žádná aplikace $v$ češtině, která by se dopadem potravin na životní prostředí zaměřovala do detailu. Téměř všechny zmíněné kalkulačky zahrnují například potraviny na úrovni "maso", přičemž nezohledňují různé druhy masa a masných výrobků (které mohou mít výrazně rozdílné dopady na životní prostředí) či "lokální potraviny”, přičemž v tomto ohledu nerozlišují různé typy potravin (které budou způsobovat opět rozdílné dopady dle typu a období produkce).

Takové detailní zaměření na potraviny by nebylo z pochopitelných důvodů u zmíněných kalkulaček ani praktické, protože většina z nich se na úrovni výpočtů osobních stop snaží $v$ minimu otázek pokrýt celý životní styl jedince od spotřeby potravin až po četnost cestování letadlem. Vzhledem k významnosti dopadů produkce a spotřeby potravin na životní prostředí a potenciální velké variabilitě ve výsledcích, je však bezesporu vhodné, aby začaly vznikat také vzdělávací a osvětové nástroje, které se zaměří právě na dopady z jídla $v$ mnohem podrobnější podobě, než jaká je v současnosti veřejně dostupná.

Jedním z takových nástrojů hodnotícím dopady spotřeby potravin, který je v současné době vyvíjen pracovníky Univerzity Karlovy (autorka tohoto článku je hlavní řešitelkou projektu) a který bude brzy dostupný veřejnosti, je nová webová aplikace - tzv. Kalkulačka Nutriční stopy. Kalkulačka umožňuje uživatelům spočítat si dopad vybraného pokrmu na životní prostředí na jednu porci a zároveň zobrazuje výživové hodnoty pokrmu, které se vztahují ke zdraví konzumenta. Kalkulačka vznikla na základě konceptu tzv. Nutriční stopy a zaměřuje se na propojení environmentální udržitelnosti a zdravé výživy člověka.

\section{Představení konceptu Nutriční stopy}

Koncept Nutriční stopy (angl. Nutritional Footprint) vznikl v Německu na základě zahraničního výzkumu spotřebních vzorců $v$ oblasti potravin vzhledem $\mathrm{k}$ nutričním a environmentálním aspektům (Lukas et al., 2013; Lukas et al., 2016). Ve své původní verzi integruje sadu indikátorů vztahujících se $\mathrm{k}$ výživovým hodnotám pokrmu a jeho dopadům na životní prostředí do jednoho agregovaného indikátoru (4 indikátory pro zdraví a 4 indikátory pro životní prostředí; Lukas et al., 2016). 
Tento koncept $z$ Německa prošel $v$ rámci řešení projektu aplikovaného výzkumu na Univerzitě Karlově revizí a na základě konzultací s českými odborníky z oblasti hodnocení dopadů na životní prostředí, vzdělávání a výživy a zdraví byl upraven. výpočet Nutriční stopy $\checkmark$ české verzi proto zahrnuje agregaci pěti indikátorů dopadu do jednoho výsledku na jednu porci pokrmu a to pouze pro oblast životního prostředí. Výživové údaje s ohledem na zdraví jsou pro pokrm také počítány, ale jsou prezentovány jako dodatečné informace a nejsou agregovány s hodnotami dopadu na životní prostředí.

Vybrané indikátory a postup výpočtu vzešel z konzultací se 14 odborníky na environmentální indikátory z celkového počtu 29 odborníků, se kterými byl projekt Nutriční stopy konzultován (viz Příloha 1). Výběr indikátorů probíhal nejprve na základě rešerše literatury specifiky se zaměřující na dopady spotřeby potravin na životní prostředí. $Z$ této rešerše vzešly nejčastěji využívané indikátory, které byly následně konzultovány se zmíněnými 14 odborníky s ohledem na jejich vhodnost a možnosti agregace do výsledné hodnoty Nutriční stopy. Tímto procesem bylo vybráno zmíněných pět indikátorů.

Větší část $\mathrm{z}$ těchto 14 odborníků agregaci pro indikátory dopadů na životní prostředí společně $s$ indikátory dopadů na zdraví do jednoho čísla pro pokrmy nedoporučila. Agregace pro indikátory dopadů v oblasti životního prostředí byla naproti tomu zmiňována jako možná a z pohledu odborníků ve vzdělávání nutná (aby koncový uživatel porovnával pouze jedno číslo a nikoli sadu několika čísel). Současná podoba výpočtu byla proto zvolena také s ohledem na srozumitelnost pro koncového uživatele, protože součástí projektu byla od začátku kromě revize indikátorů Nutriční stopy také tvorba Kalkulačky Nutriční stopy cílená na širokou veřejnost $\mathrm{v}$ ČR. Koncept Nutriční stopy je poměrně mladý a bude se zajisté do budoucna nadále vyvíjet. Aktuální verze konceptu však poskytuje dobrý rámec pro výpočet environmentálních dopadů z jídel a současnou prezentaci výživových hodnot relevantních pro zdraví člověka.

Tento př́stup odpovídá snaze nalézt rovnováhu mezi zdravým stravováním s co nejmenším dopadem na životní prostředí. Článek tedy představuje koncept a vznikající kalkulačky v širším kontextu využívání environmentálních stop ve vzdělávání v ČR (než aby poskytoval vyčerpávající informace o vývoji kalkulačky, které by měly následovat $v$ dalším článku).

\section{Vlastní výpočet NS}

Pro výpočet jednotlivých indikátorů environmentální zátěže pokrmu na životní prostředí byly uvažovány jak ingredience, tak spotřeba energie potřebné pro prípravu pokrmu. Pro výpočet výživových hodnot pokrmu byly uvažovány pouze ingredience. Environmentální zátěž jídel je vypočítána pro pět dopadových kategorií - změna klimatu, terestrická acidifikace („okyselování"), sladkovodní eutrofizace („nadbytek živin ve vodě”), využití území („zábor půdy”) a využití vody („úbytek vody") - dle následujícího vzorce:

$$
Y_{\text {kat }}=\left[\left(\sum x_{i} / 1000 * y_{i}\right)+\left(t * y_{e}\right)\right] / a
$$

kde $\mathrm{Y}_{\text {kat }}=$ celkový dopad kategorie za jednu porci pokrmu ( $\mathrm{v}$ jednotkách $\mathrm{kg} \mathrm{CO}_{2}$ eq., $\mathrm{kg} \mathrm{SO}_{2}$ eq., $\mathrm{kg} \mathrm{P}$ eq., $\mathrm{m}^{2} \mathrm{a}$ a $\mathrm{m}^{3}$, respektive pro jednotlivé dopadové kategorie), $\mathrm{x}_{\mathrm{i}}=\mathrm{množství}$ ingredience $v$ receptuře $(g), y_{i}=$ dopad ingredience ( $v$ jednotkách $\mathrm{kg} \mathrm{CO}_{2}$ eq., $\mathrm{kg} \mathrm{SO}_{2}$ eq., 
$\mathrm{kg} P$ eq., $\mathrm{m}^{2} \mathrm{a} a \mathrm{~m}^{3}$ na $1 \mathrm{~kg}$ ingredience), $\mathrm{t}=$ délka použití spotřebiče (elektrické energie), $\mathrm{y}_{\mathrm{e}}=$ dopad spotřebiče (elektrické energie $\left.{ }^{6}\right), \mathrm{a}=$ počet porcí

Dalším krokem výpočtu Nutriční stopy je škálování a agregace do jedné výsledné hodnoty, pro které se vyslovila většina expertů v rámci odborných konzultací. Během škálování jsou jednotlivé výsledky $Y_{\text {kat }}$ zařazeny dle pětistupňové škály do skupin od 1 do 5 pro každou z pěti dopadových kategorií. Tyto skupiny jsou následující:

- 1 = velmi nízká zátěž

- 2 = nízká zátěž

- 3 = střední zátěž

- 4 = vysoká zátěž

- $\quad 5$ = velmi vysoká zátěž

Rozsah škály je určen na základě literatury (Lukas et al., 2016) a dle relativních dopadů $v$ jednotlivých kategoriích vzhledem $\mathrm{k}$ celkovému spektru spočítaných pokrmů tak, aby byly stanoveny hranice nejnižšího a nejvyššího maximálního možného dopadu na jednu porci pokrmu pro každou kategorii (Tabulka 3). $V$ testovací fázi výpočtu Nutriční stopy byl použit také výpočet celkového výsledku na energetickou hodnotu pokrmu (aby se nemusela řešit různá velikost porcí), ale výsledky vyšly prakticky stejně u všech testovaných pokrmů jako výsledky na 1 porci pokrmu. Proto byla pro výsledný výpočet zvolena uživatelsky př́ivětivější jednotka jedné porce pokrmu.

Konzultace expertů mimo jiné ukázaly na potřebnost agregace jednotlivých pěti dopadů na životní prostředí do jednoho finálního indikátoru, který je $z$ hlediska běžného uživatele z řad veřejnosti kvůli snadné orientaci ve výsledcích nezbytností. Výsledná Nutriční stopa je proto vyjádřena jedním číslem jako:

NS $=\left(Y_{\text {změna klimatu 1-5 }}+Y_{\text {acidifikace 1-5 }}+Y_{\text {eutrofizace 1-5 }}+Y_{\text {využití území 1-5 }}+Y_{\text {využití vody 1-5 }}\right) / 5$

Jednotlivé kategorie dopadu jsou agregovány egalitářským způsobem, tzn. všem pěti kategoriím dopadu byla přiřazena stejná váha ( $v$ tomto přístupu se neuvažuje nadřazenost některé z kategorií dopadu nad jinými). Celkový výsledek je zařazen do jedné z pěti finálních kategorií dopadu: velmi malý dopad, malý dopad, střední dopad, vysoký dopad a velmi vysoký dopad (viz Tabulka 3).

\footnotetext{
${ }^{6}$ Dopad spotřeby elektřiny na životní prostředí se liší v jednotlivých zemích v závislosti na energetickém mixu výroby elektřiny $v$ dané zemi. Vzhledem $k$ tomu, že kalkulačka bude $v$ době zveřejnění pouze $v$ českém jazyce, je dopad modelován pro český energetický mix. Pokud by se však do budoucna kalkulačka rozšiřovala i o další jazykové verze, bylo by třeba toto specifikum zohlednit.
} 
Tabulka 3. Systém škálování a agregace pro stanovení výsledné hodnoty Nutriční stopy pokrmu

\begin{tabular}{|c|c|c|c|c|c|c|c|}
\hline 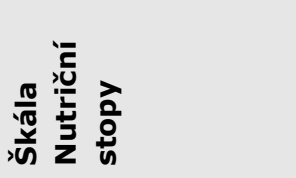 & 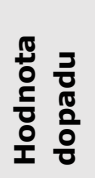 & 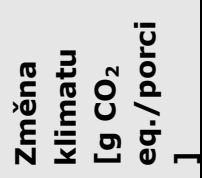 & 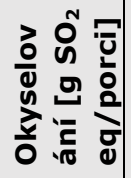 & 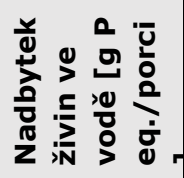 & 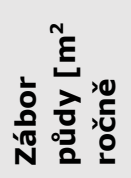 & 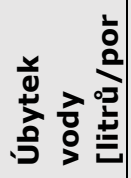 & 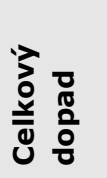 \\
\hline velmi malý dopad & 1 & $0-400$ & $0-15$ & $0-0,15$ & $0-0,05$ & $0-15$ & $1-1,5$ \\
\hline malý dopad & 2 & $401-800$ & $\begin{array}{l}16- \\
30\end{array}$ & $0,16-0,3$ & $\begin{array}{l}0,6- \\
1,0\end{array}$ & $16-30$ & $\begin{array}{l}1,6- \\
2,5\end{array}$ \\
\hline střední dopad & 3 & $801-1200$ & $\begin{array}{l}31- \\
45\end{array}$ & $\begin{array}{l}0,31- \\
0,45\end{array}$ & $\begin{array}{l}1,1- \\
1,5\end{array}$ & $\begin{array}{l}31- \\
45\end{array}$ & $\begin{array}{l}2,6- \\
3,5\end{array}$ \\
\hline vysoký dopad & 4 & $\begin{array}{l}1201- \\
1600\end{array}$ & $\begin{array}{l}46- \\
60\end{array}$ & $0,46-0,6$ & $\begin{array}{l}1,6- \\
2,0\end{array}$ & $\begin{array}{l}46- \\
60\end{array}$ & $\begin{array}{l}3,6- \\
4,5\end{array}$ \\
\hline $\begin{array}{l}\text { velmi vysoký } \\
\text { dopad }\end{array}$ & 5 & $>1600$ & $>60$ & $>0,6$ & $>2,0$ & $>60$ & $4,6-5$ \\
\hline
\end{tabular}

Nutriční hodnoty pro zvolených pět kategorií - tj. energetická hodnota, tuky, nasycené mastné kyseliny, cukry a sůl - jsou vypočítány na základě doporučeného postupu EuroFIR (Machackova et al., 2015) dle vzorce upraveného na jednu porci pokrmu:

$$
N_{\text {nutri }}=\left[\sum x_{i}{ }^{*} k_{i}{ }^{*} z_{i} / 100\right] / a
$$

kde $N_{\text {nutri }}=$ obsah výživové hodnoty na jednu porci pokrmu ( $v$ gramech, $g$ ), $x_{i}=$ množství ingredience $v$ receptuře $(g), k_{i}=$ koeficient jedlého podílu ingredience, $z_{i}=$ obsah látky $v$ ingredienci (na $100 \mathrm{~g}$ jedlého podílu), a = počet porcí

Výživové hodnoty jsou zobrazovány jako doplňující informace vedle environmentálních dopadů a celkového výsledku Nutriční stopy.

\section{Příklad výpočtu Nutriční stopy}

Výpočet Nutriční stopy je ilustrován v Tabulce 4 na př́ikladu dvou vybraných pokrmů: 1) karbanátky se štouchanými brambory a 2) čočka na kyselo s vejcem. Nutriční stopa pro pokrm s karbanátky má hodnotu 4 - vysoký dopad, kdežto NS pro čočku má hodnotu 2,4 malý dopad. Vysoký dopad u prvního pokrmu je dán zejména použitím hovězího a vepřového masa $v$ receptu, které způsobují relativně vysoké dopady ve všech kategoriích dopadu (od středního po velmi vysoký). U pokrmu s čočkou je naopak většina kategorií dopadu relativně malá a vyšší je u dvou kategorié dopadu - změny klimatu (z důvodu dovozu čočky z Kanady a zahrnutím vajec $v$ receptu) a záboru půdy (kvůli relativně nízkým výnosům čočky, která je produkována na poměrně velkých plochách).

Při pohledu na výživové hodnoty s ohledem na zdraví je pak zřejmé, že u těchto dvou pokrmů by si spotřebitelé měli hlídat zejména celkovou spotřebu tuků, nasycených mastných kyselin a soli, které v několika případech přesahují hodnotu $50 \%$ výživové doporučené denní dávky na danou jednu porci pokrmu. To je způsobeno zejména použitím ingrediencí obsahující tuky živočišného původu (máslo, hovězí a vepřové maso) a vyšším množstvím přidané soli v receptu na čočku. 
Tabulka 4. Příklad výpočtu Nutriční stopy a výživových hodnot pro dva vybrané pokrmy; ŽP = životní prostředí, V\&Z = výživa a zdraví, VDD = výživová denní doporučená dávka; výpočty pro životní prostředí byly provedeny na základě databáze environmentálních dopadů pro dané ingredience vytvořené Centrem pro otázky životního prostředí Univerzity Karlovy, výživové hodnoty byly stanoveny na základě dat z NutriDatabáze.cz poskytnuté Ústavem zemědělské ekonomiky a informací.

\begin{tabular}{|c|c|c|c|c|}
\hline VSTUPY & \multicolumn{2}{|c|}{$\begin{array}{l}\text { Karbanátky se štoucha- } \\
\text { nými brambory }\end{array}$} & \multicolumn{2}{|c|}{ Čočka na kyselo s vejcem } \\
\hline $\begin{array}{l}\text { Ingredience na } \\
1 \text { porci pokrmu }\end{array}$ & \multicolumn{2}{|c|}{$\begin{array}{l}40 \mathrm{~g} \text { hovězího mletého masa } \\
30 \mathrm{~g} \text { vepřového meltého masa } \\
5 \mathrm{~g} \text { cibule } \\
3 \mathrm{~g} \text { soli } \\
1 \mathrm{~g} \text { česneku } \\
0,1 \mathrm{~g} \text { černého pepře } \\
0,1 \mathrm{~g} \text { majoránky } \\
15 \mathrm{~g} \text { vejce } \\
26 \mathrm{~g} \text { strouhanky } \\
13 \mathrm{~g} \text { hladké pšeničné mouky } \\
10 \mathrm{~g} \text { kravského polotučného mléka } \\
20 \mathrm{~g} \text { řepkového oleje } \\
250 \mathrm{~g} \text { brambor } \\
15 \mathrm{~g} \text { másla }\end{array}$} & \multicolumn{2}{|c|}{$\begin{array}{l}112,5 \mathrm{~g} \text { čočky } \\
15 \mathrm{~g} \text { cibule } \\
20 \mathrm{~g} \text { řepkového oleje } \\
3 \mathrm{~g} \text { hladké pšeničné mouky } \\
3 \mathrm{~g} \text { soli } \\
3 \mathrm{~g} \text { octa } \\
2 \mathrm{ks} \text { vajec }\end{array}$} \\
\hline $\begin{array}{l}\text { Příprava na } 1 \\
\text { porci pokrmu }\end{array}$ & \multicolumn{2}{|c|}{$\begin{array}{l}\text { Usmažení karbanátků - } 40 \text { min na } \\
\text { oleji, uvaření brambor - } 20 \text { min ve } \\
100 \text { ml vody, vše na elektrické in- } \\
\text { dukční desce }\end{array}$} & \multicolumn{2}{|c|}{$\begin{array}{l}\text { Uvaření čočky - } 30 \text { min ve } 100 \\
\text { ml vody, usmažení cibulky - } \\
15 \text { min na oleji, uvaření vajec } \\
-15 \text { min ve } 100 \mathrm{ml} \text { vody, vše } \\
\text { na elektrické indukční desce }\end{array}$} \\
\hline $\begin{array}{l}\text { VÝSLEDKY - } \\
\text { ŽP }\end{array}$ & Hodnota & Relativní dopad & Hodnota & $\begin{array}{l}\text { Relativní do- } \\
\text { pad }\end{array}$ \\
\hline $\begin{array}{l}\text { Změna klimatu } \\
{\left[\mathrm{g} \mathrm{CO}_{2} \text { eq. / }\right.} \\
\text { porci }]\end{array}$ & 1728 & 5 - velmi vysoký dopad & 919 & $\begin{array}{l}3 \text { - střední do- } \\
\text { pad }\end{array}$ \\
\hline $\begin{array}{l}\text { Okyselování } \\
\text { prostředí } \\
{\left[\mathrm{g} \mathrm{SO}_{2} \text { eq. / }\right.} \\
\text { porci] }\end{array}$ & 36 & 3 - střední dopad & 19 & 2 - malý dopad \\
\hline $\begin{array}{l}\text { Nadbytek živin } \\
\text { ve vodě } \\
\text { [g P eq. / porci] }\end{array}$ & 0,47 & 4 - vysoký dopad & 0,29 & 2 - malý dopad \\
\hline $\begin{array}{l}\text { Zábor půdy } \\
{\left[\mathrm{m}^{2} \text { za rok / }\right.} \\
\text { porci] }\end{array}$ & 2,6 & 5 - velmi vysoký dopad & 1,6 & $\begin{array}{l}4 \text { - vysoký do- } \\
\text { pad }\end{array}$ \\
\hline $\begin{array}{l}\text { Úbytek vody } \\
\text { [litrů / porci] }\end{array}$ & 33 & 3 - střední dopad & 14 & $\begin{array}{l}1 \text { - velmi malý } \\
\text { dopad }\end{array}$ \\
\hline $\begin{array}{l}\text { NUTRIČNÍ } \\
\text { STOPA }\end{array}$ & \multicolumn{2}{|c|}{4 - vysoký dopad } & \multicolumn{2}{|c|}{2,4 - malý dopad } \\
\hline
\end{tabular}




\begin{tabular}{|l|l|l|l|l|}
\hline $\begin{array}{l}\text { VÝSLEDKY - } \\
\text { V\&Z }\end{array}$ & Hodnota & \%VDD & Hodnota & \%VDD \\
\hline $\begin{array}{l}\text { Obsah energie } \\
\text { [k] / porci] }\end{array}$ & 3046 & 36 & 3018 & 36 \\
\hline $\begin{array}{l}\text { Obsah tuků [g / } \\
\text { porci] }\end{array}$ & 41,6 & 59 & 31,9 & 46 \\
\hline $\begin{array}{l}\text { Nasycené } \\
\text { mastné kyseliny } \\
\text { [g / porci] }\end{array}$ & 11,9 & 60 & 4,3 & 21 \\
\hline $\begin{array}{l}\text { Cukry [g / } \\
\text { porci] }\end{array}$ & 3,1 & 3 & 1,2 & 1 \\
\hline Sůl [g / porci] & 3.4 & 56 & 3,3 & 54 \\
\hline
\end{tabular}

\section{Vývoj Kalkulačky Nutriční stopy}

Výpočty zmíněné výše jsou využity ve webové aplikaci, tj. Kalkulačce Nutriční stopy, kde jsou propojeny s databází dopadů na životní prostředí (vlastní databáze na základě modelování pomocí posuzování dopadů na životní prostředí - LCA) a databází výživových hodnot (databáze od ÚZEI, viz Poděkování) pro jednotlivé potraviny. Uživatel si tedy může vypočítat dopady $z$ jedné porce zvoleného pokrmu $v$ pěti dopadových kategoriích na životní prostředí, celkové skóre Nutriční stopy (tj. jeden agregovaný výsledek zobrazující se systémem semaforu od zelené po červenou, viz Tabulka 3) a také výživové hodnoty s ohledem na zdraví (viz Tabulka 4).

Kalkulačka byla vyvinuta řešitelským týmem z Centra pro otázky životního prostředí Univerzity Karlovy, její vývoj byl však konzultován s mnoha aktéry ze sféry neziskové (např. TEREZA, Glopolis), státní (např. MŽP), akademické (např. odborníci z UK, VŠCHT, ETH Zurich) i privátní (např. Eaternity) - více viz Poděkování. V současnosti dochází k finálním úpravám aplikace, která bude zveřejněna na přelomu roku 2017/2018.

\section{Kalkulačka Nutriční stopy a vzdělávání}

Hlavním cílem projektu "Nutriční stopy” je zvýšení povědomí o provázanosti spotřeby potravin s dopady na naše společné životní prostředí a na individuální zdraví člověka. Kalkulačka Nutriční stopy má v širším kontextu sloužit pro osvětu a vzdělávání široké veřejnosti (věkový rozsah zhruba 15+) v ČR směrem $k$ udržitelné spotřebě potravin. Tato webová aplikace je tedy nový vzdělávací a osvětový nástroj, který bude zdarma dostupný komukoli $\mathrm{s}$ prístrojem $\mathrm{s}$ internetovým připojením (chytrý mobilní telefon, tablet či počítač). Kromě široké veřejnosti se řešitelský tým snaží v rámci realizace projektu zacílit také na učitele a další vzdělavatele, kteří by mohli kalkulačku využívat v rámci výuky či dalších vzdělávacích aktivitách se žáky a studenty.

$Z$ tohoto důvodu byla kalkulačka během vývoje testována $v$ několika krocích s vybranými zástupci z řad budoucích uživatelů, aby byla přívětivá pro koncového uživatele (at́ už se jedná o "běžného" občana, nebo učitele a jeho žáků). Z rozhovorů a pilotního workshopu, které se uskutečnily $v$ průběhu roku 2017, vyplynulo, že si dotazovaní učitelé dovedou v principu představit využívání Kalkulačky Nutriční stopy ve výuce či v extrakurikulárních aktivitách. Rádi by však $\mathrm{k}$ nástroji měli také kompletní metodické dokumenty, které by mohli využít (podrobnější informace o testování a jeho výsledcích budou v dalším článku). 
Zpětná vazba a informace získané během testování beta verze kalkulačky budou zohledněny ve finální verzi aplikace, jejíž zveřejnění se plánuje na začátek roku 2018. V jednání je momentálně také budoucí spolupráce s neziskovými organizacemi na vytvoření metodických materiálů pro učitele specificky k využití kalkulačky ve vzdělávání.

\section{Diskuze ke Kalkulačce Nutriční stopy}

\section{Kalkulačka Nutriční stopy v kontextu environmentálních stop}

Při pohledu na existující kalkulačky environmentálních stop v češtině (Tabulka 1) je možné konstatovat, že Kalkulačka Nutriční stopy je v mnoha ohledech unikátní. Kalkulačka je $v$ současnosti např́klad jedinou webovou aplikací (či podobným nástrojem) v češtině, která se podrobně zabývá dopady spotřeby potravin na životní prostředí. Je to také jediná kalkulačka, která obsahuje zhodnocení dopadu na životní prostředí v pěti dopadových kategoriích a agreguje výsledky do jednoho výsledného indikátoru, tj. výsledné hodnoty Nutriční stopy. Ostatní kalkulačky se téměř výhradně zaměřují na jednu kategorii dopadu - např. uhlíkovou či vodní stopu. Výjimkou je ekologická stopa, která je také agregovaným indikátorem (viz Tabulka 5).

Všechny typy environmentálních stop a jejich kalkulačky pochopitelně mají své silné a slabé stránky, které jsou podrobněji z pohledu autorky tohoto textu rozvedeny $v$ Tabulce 5. Silnou stránkou kalkulaček zaměřujících se na jednu kategorii dopadu (uhlíková stopa, př́padně vodní v podobě zahraničních kalkulaček) je relativně snadné pochopení výsledku koncovým uživatelem. Slabou stránkou těchto kalkulaček je zaměření se právě na jednu kategorii dopadu, přičemž dopad na životní prostředí může být v jiné, neměřené, kategorii dopadu mnohem závažnější.

U kalkulaček environmentálních stop tedy existuje jisté dilema mezi komplexností (z vědeckého pohledu) a srozumitelností (z pohledu uživatele), což je v prípadě zahrnutí potravin obzvláště markantní z důvodu komplexnosti potravinových systémů a šíře dopadů na životní prostředí. Kalkulačka Nutriční stopy se snaží najít mezi těmito dvěma důležitými aspekty rovnováhu tím, že pro zvolený pokrm prezentuje jak pět dopadů na životní prostředí, tak agregovaný výsledek Nutriční stopy v jednom čísle a pro všechny hodnoty uživateli pomáhá s porozuměním závažnosti dopadu pomocí škálování a "systému semaforu” (tj. zelená = relativně nízký dopad, červená = relativně vysoký dopad, viz Tabulka 3).

Ani Kalkulačku Nutriční stopy však nelze považovat za dokonalý nástroj bez slabých stránek. Jako problematické se může jevit například vyjádření výsledné hodnoty Nutriční stopy na jednu porci pokrmu, jejiž velikost určuje uživatel. Zde je také třeba zdưraznit, že současná podoba kalkulačky je naškálovaná na šíri dopadů z typických hlavních jídel. Tyto aspekty byly podrobeny během vývoje aplikace bližšímu zkoumání a na základě výpočtů pro testovací pokrmy došel řešitelský tým k závěru, že se jedná o nejvhodnější současné uspořádání (přepočet dopadu na energetický obsah v kJ, který by vyřešil problematiku rưzné velikosti porcí, totiž ukázal, že výsledky vycházejí téměř identicky, ale nejsou tolik pochopitelné pro koncového uživatele, jako vyjádření na 1 porci pokrmu).

Další výtkou může být již výše zmíněný výčet environmentálních dopadů zahrnutý ve výpočtu Nutriční stopy, který není z hlediska šíre oblastí životního prostředí ani $v$ tomto případě vyčerpávající, protože ne všechny dopady umí výzkumníci vyjádřit číselnou hodnotou na $1 \mathrm{~kg}$ finálního produktu. Toto se týká například snižování biodiverzity či degradace půdy. Mưže se tedy stát, že pokrm, který vychází jako relativně environmentálně přivětivý na základě současných pěti indikátorů dopadu, by byl z pohledu úbytku biodiverzity velmi 
zatěžující. Do budoucna tedy musí být snaha výzkumníků a vývojářů kalkulaček environmentálních stop zohlednit také tyto zatím těžko vyčílitelné oblasti životního prostředí.

$\checkmark$ neposlední řadě může být diskutována také vhodnost normalizace a agregace pěti kategorií dopadu do jedné výsledné hodnoty Nutriční stopy na základě egalitářského přístupu, který volí průměr naškálovaných hodnot bez toho, aby některou z kategorií považoval za více či méně důležitou. Téma normalizace a vážení je často diskutované v literatuře zabývající se posuzováním dopadů na životní prostředí, neexistuje však v současné době jeden přistup, který by byl považován ze jediný správný (Hofstetter et al., 2000; Pizzol et al., 2017). Proto byl zvolen př́stup nejméně kontroverzní, který považuje všechny kategorie dopadu za stejně důležité (což však nemusí reflektovat skutečnost $v$ přírodních systémech).

Tuto diskuzní část bych tedy uzavřela tvrzením, že Kalkulačka Nutriční stopy je založena na nejnovějších vědeckých datech a přistupech, které se však do budoucna budou zcela jistě na základě nového výzkumu dále vyvíjet. Finální verze kalkulačky pak také zohlední poznatky získané v první části tohoto článku a bude se snažit vyvarovat nedostatkům identifikovaným výše, tj. zveřejní zdroje primárních dat, přesný postup výpočtů, veškeré předpoklady a nejistoty spojené $s$ výpočty, datum zveřejnění kalkulačky a také datum poslední aktualizace, aby měl uživatel $k$ dispozici všechny potřebné informace ohledně toho, kde se výsledná čísla berou a jak jsou aktuální.

Svým zaměřením na potraviny je Kalkulačka Nutriční stopy vhodná zejména pro hlubší zamyšlení se nad tím, co uživatelé jedí a jak mohou změnou ve svém jídelníčku přispět ke svému zdravějšímu stravování s nižšími dopady na životní prostředí. Její využití může následovat např́klad poté, co si uživatel již spočítal svoji osobní stopu (např. jednou z existujících kalkulaček environmentálních stop) a dozvěděl se, že dopad na životní prostředí je do velké míry ovlivněn jeho stravovacími preferencemi. Případně může být využita vzdělavateli v různých výukových a osvětových aktivitách. 
Tabulka 5. Nutriční stopa v kontextu přehledu nejčastějších environmentálních stop a jejich kalkulaček (částečně na základě kalkulaček $v$ češtině $v$ Tabulce 1 ).

\begin{tabular}{|c|c|c|c|}
\hline $\begin{array}{l}\text { Ná- } \\
\text { zev } \\
\text { stopy }\end{array}$ & Co stopa počítá & Silné stránky* & Slabé stránky* \\
\hline $\begin{array}{l}\text { Uhlí- } \\
\text { ková } \\
\text { stopa }\end{array}$ & $\begin{array}{l}\text { Množství vyproduko- } \\
\text { vaných skleníkových } \\
\text { plynů vyjádřených v } \\
\text { ekvivalentech oxidu } \\
\text { uhličitého }\left(\mathrm{CO}_{2} \text { eq. }\right)\end{array}$ & $\begin{array}{l}\text { Jasná interpretace } \\
\text { výsledků vzhledem k } \\
\text { environmentálnímu } \\
\text { problému, který popi- } \\
\text { suje (globální změna } \\
\text { klimatu) }\end{array}$ & $\begin{array}{l}\text { Zaměření se pouze na jeden } \\
\text { dopad na ŽP, kdy hrozí, že } \\
\text { jiný - závažnější dopad - ne- } \\
\text { bude odhalen, ačkoli výsledek } \\
\text { uhlíkové stopy mưže pro daný } \\
\text { výpočet vypadat environmen- } \\
\text { tálně příznivě }\end{array}$ \\
\hline $\begin{array}{l}\text { Ekolo- } \\
\text { gická } \\
\text { stopa }\end{array}$ & $\begin{array}{l}\text { Kolik průměrné pro- } \\
\text { duktivní plochy Země } \\
\text { je třeba k zajištění } \\
\text { využívaných zdrojů a } \\
\text { zneškodnění dopadů } \\
\text { s tím souvisejících } \\
\text { vyjádřené v globál- } \\
\text { ních hektarech (gha) }\end{array}$ & $\begin{array}{l}\text { Názorná pochopitel- } \\
\text { nost dopadu na ži- } \\
\text { votní prostředí pro } \\
\text { koncového uživatele } \\
\text { díky vyjádření v ploš- } \\
\text { ných jednotkách (po- } \\
\text { čet planet Země), } \\
\text { které člověk využívá }\end{array}$ & $\begin{array}{l}\text { Zaměřuje se na dva environ- } \\
\text { mentální problémy (užití půdy } \\
\text { a globální změnu klimatu), za- } \\
\text { tímco ostatní environmentální } \\
\text { problémy nejsou zohledněny. } \\
\text { V odborné literatuře je kon- } \\
\text { cept kritizován kvůli omezené } \\
\text { aplikovatelnosti pro potřeby } \\
\text { politik a environmentálního } \\
\text { plánování (např. Fiala, 2008; } \\
\text { Wiedmann \& Barrett, 2010; } \\
\text { Blomqvist et al., 2013) }\end{array}$ \\
\hline $\begin{array}{l}\text { Vodní } \\
\text { stopa }\end{array}$ & $\begin{array}{l}\text { Kolik sladké vody se } \\
\text { využije při dané lid- } \\
\text { ské činnosti vyjád- } \\
\text { řené v objemu vody } \\
\text { v litrech (I) - nejčas- } \\
\text { těji se počítá modrá, } \\
\text { zelená a šedá vodní } \\
\text { stopa (dle Water } \\
\text { Footprint Network) }\end{array}$ & $\begin{array}{l}\text { Snadná pochopitel- } \\
\text { nost pro koncového } \\
\text { uživatele díky objemu } \\
\text { spotřebované vody v } \\
\text { litrech }\end{array}$ & $\begin{array}{l}\text { Zaměření se pouze na jeden } \\
\text { dopad na ŽP (viz uhlíková } \\
\text { stopa), v současnosti neexis- } \\
\text { tuje konsenzus ohledně jed- } \\
\text { noho univerzálního výpočtu } \\
\text { vodní stopy a jeho vhodnosti } \\
\text { (viz např. Hoekstra, 2016; } \\
\text { Pfister et al., 2017) }\end{array}$ \\
\hline $\begin{array}{l}\text { Nu- } \\
\text { triční } \\
\text { stopa }\end{array}$ & $\begin{array}{l}\text { Závažnost dopadu na } \\
\text { životní prostředí ze } \\
\text { spotřeby jedné porce } \\
\text { pokrmu vyjádřené na } \\
\text { škále od } 1 \text { do } 5 \text { a } \\
\text { zvýrazněné systé- } \\
\text { mem semaforu (od } \\
\text { zelené po červenou) } \\
\text { - jedná se o agregát } \\
\text { pěti kategorií dopadu }\end{array}$ & $\begin{array}{l}\text { Kombinace více kate- } \\
\text { gorií dopadu na ži- } \\
\text { votní prostředí do } \\
\text { jednoho výsledku, } \\
\text { který je pro konco- } \\
\text { vého uživatele pocho- } \\
\text { pitelný (díky vyjád- } \\
\text { ření závažnosti po- } \\
\text { mocí semaforu), za- } \\
\text { měření specificky na } \\
\text { potraviny }\end{array}$ & $\begin{array}{l}\text { Náročnost na data a nezahr- } \\
\text { nutí dalších dopadů na ŽP jako } \\
\text { je biodiverzita či degradace } \\
\text { půdy (což je ale stejné pro } \\
\text { všechny ostatní stopy), nee- } \\
\text { xistuje také univerzálně uzná- } \\
\text { vaný výpočet, protože se } \\
\text { jedná o velmi mladý koncept } \\
\text { (zatím čeká na podrobení kri- } \\
\text { tice v mezinárodních časopi- } \\
\text { sech) }\end{array}$ \\
\hline
\end{tabular}




\section{Nutriční stopa a budoucí výzkum}

Budoucí výzkum zaměřující se na koncept Nutriční stopy a nástrojů pro jeho praktické využití (např. ve formě vyvíjené kalkulačky) by se měl zaměřit na dvě hlavní roviny:

1) „zlepšování kalkulačky” a

2) „efektivnost kalkulačky”.

V prvním případě - „zlepšování kalkulačky" - se jedná o vývoj samotného konceptu Nutriční stopy a získávání nejnovějších podkladových dat pro její výpočet. Zde by bylo možné zmínit například zahrnutí dopadů na snižování biodiverzity do celkového výsledku Nutriční stopy, nebo rozšiřování databáze ingrediencí, se kterými kalkulačka počítá (např. více zemí původu, typy produkčních systémů, měsíc produkce, atp.).

Ve druhém případě - "efektivnost kalkulačky” - by se budoucí výzkum měl snažit zhodnotit, do jaké míry má kalkulačka kýžený efekt na koncového uživatele. Zde by bylo vhodné provést studie, které by ukazovaly, zda zkušenost s kalkulačkou zvyšuje nejen informovanost a kompetence $v$ oblasti environmentálně udržitelné spotřeby potravin, ale zda ve výsledku přispívá také ze změně spotřebitelského chování či nikoli. Některé zahraniční studie totiž ukazují, že veřejně dostupné kalkulačky environmentálních stop nemusí mít ve skutečnosti zamýšlený pozitivní dopad na změnu spotřebitelského chování (Franz \& Papyrakis, 2011). Jedná se např́klad o kalkulačky, u kterých absentuje možnost snížit dopad jednotlivce na úroveň, která se dá považovat za environmentálně udržitelnou, což mưže mít demotivující efekt na uživatele pokusit se cokoli ve svém životě změnit (Franz \& Papyrakis, 2011). Z tohoto důvodu také nabízí Kalkulačka Nutriční stopy uživatelům vyzkoušení pokrmů, které jsou relativně environmetnálně příznivé. Všeobecně však existuje velký prostor pro další výzkum, který by otázku pozitivního efektu na spotřebitelské chování blíže osvětlil nejen ve vztahu ke Kalkulačce Nutriční stopy, ale také případným dalším podobným nástrojům v ČR.

\section{Shrnutí studie a závěr}

Současná produkce a spotřeba potravin není z dlouhodobého hlediska udržitelná. Přibývá čím dál větší počet odborníků, kteří se shodují, že je proto třeba změnit naše stravování a hledat „udržitelnější" možnosti. Environmentální stopy a nástroje s nimi spojené (nejčastěji tzv. kalkulačky environmentálních stop) mohou být jedním z vhodných přístupů, jak se snažit o těchto problémech informovat širokou veřejnost a (snad) ve výsledku přispět také ke změně spotřebitelského chování. $V$ současné době existuje $v$ ČR poměrně málo kalkulaček environmentálních stop $v$ češtině, které zahrnují oblast potravin. Tento článek představuje nový koncept tzv. Nutriční stopy a s ním spojenou kalkulačku, která je vyvíjena na Univerzitě Karlově a která se specificky zabývá dopady produkce a spotřeby potravin a neopomíjí ani význam jejich výživových hodnot...

Ačkoli jsou kalkulačky environmentální stop jistě prospěšné pro veřejnost, mají i své nedostatky. Součástí každé veřejně dostupné kalkulačky by proto měly být také informace, které jsou často opomíjeny, tj. zdroje primárních dat, podrobný metodický postup výpočtu, zhodnocení nejistot výpočtů, datum zveřejnění a datum poslední aktualizace kalkulačky a v neposlední řadě upozornění, že výsledky výpočtů je třeba brát zejména orientačně. Ze studie vyplynulo, že v ČR chybí systematický výzkum, který by se využití kalkulaček v EVVO a VUR věnoval. Kalkulačky tedy jsou ve vzdělávání do určité míry využívány, neexistuje o tom však zatím žádný ucelený přehled. Tento článek je tedy zřejmě první snahou o nahlédnutí tohoto 
tématu akademickým pohledem a poskytnutí přehledu současného statu quo. Snahou je upozornit na téma environmentálních stop ve vzdělávání a snad i přispět $k$ zájmu o další výzkumy a studie na toto téma pro efektivní podporu EVVO a VUR (nejen) v oblasti udržitelné spotřeby potravin $v$ kontextu hledání udržitelného způsobu života.

\section{Poděkování}

Článek vznikl jako jeden z výstupů projektu aplikovaného výzkumu „Metodika stanovení Nutriční stopy pro vyjádření environmentálních a zdravotních aspektů spotřeby potravin v ČR" (TD03000150). Projekt probíhá v letech 2016-2017 a je spolufinancován Technologickou agenturou ČR z programu Omega. Autorka tímto velmi děkuje všem členům řešitelskému týmu z Centra pro otázky životního prostředí Univerzity Karlovy, kteří se na projektu podílí a všem dalším institucím a lidem, kteří přispěli či přispívají k úspěšné realizaci projektu, na jehož základě vznikla kalkulačka, podkladový metodický dokument a tento článek. Děkuji Odboru finančních a dobrovolých nástrojů na Ministerstvu životního prostředí (pod které spadá EVVO a VUR) za podporu projektu a zájem o jeho výstupy. Velký dík dále patří odborníkům, se kterými proběhly konzultace ohledně konceptu Nutriční stopy, grafičce a programátorovi, kteří vytvářeli kalkulačku a všem respondentům (z řad veřejnosti i učitelů) a účastníkům i organizátorům workshopu (na konferenci Menu pro změnu), kteří byli součástí testování beta verze kalkulačky v roce 2017 a přispěli tak svou zpětnou vazbou ke zlepšení uživatelské přívětivosti vznikající aplikace. Velké poděkování adresuji také koordinátorce Databáze složení potravin v ČR z Centra pro databázi složení potravin ČR v rámci Ústavu zemědělské ekonomiky a informací v Praze, jejíz vstřícnost umožnila využití této databáze $v$ naší kalkulačce. $V$ neposlední řadě si zaslouží poděkování také zahraniční organizace a instituce za podporu projektu: společnost Blonk Consultants z Holandska, společnost Eaternity ze Švýcarska, World Food Systems Centre na ETH Zurich ve Švýcarsku a Organic Food Systems Programme. Na závěr bych chtěla poděkovat také třem anonymním recenzentům, kteří svými komentáři přispěli ke zkvalitnění tohoto článku.

\section{Literatura}

- Andres, R. (2016). Adaptace na změnu klimatu ve školní praxi. Envigogika, 11(1), Retrieved from https://www.envigogika.cuni.cz/index.php/Envigogika/article/view/513 http://dx.doi.org/10.14712/18023061.513

- Bailey, R., \& Harper, D. R. (2015). Reviewing Interventions for Healthy and Sustainable Diets. Chatham House: The Royal Institute of International Affairs.

- Blomqvist, L., Brook, B. W., Ellis, E. C., Kareiva, P. M., Nordhaus, T., \& Shellenberger, M. (2013). Does the shoe fit? Real versus imagined ecological footprints. PLOS Biology, 11, 1001700-10. http://dx.doi.org/10.1371/journal.pbio.1001700

- Clonan, A., \& Holdsworth, M. . The challenges of eating a healthy and sustainable diet. American Journal of Clinical Nutrition, 96(3), 459-460. Retrieved from http://ajen.nutrition.org/cgi/doi/10.3945/ajen.112.044487 http://dx.doi.org/10.3945/ajen.112.044487

- Ekumenická akademie, (2017). Pěstuj planetu. : Ekumenická akademie. Retrieved from http://www.pestujplanetu.cz/ 
- European Commission (2016). Sustainable Food. . Retrieved from http://ec.europa.eu/environment/eussd/food.htm

- European Environment Agency (2014). Environmental indicator report 2014. Environmental impacts of production-consumption systems in Europe. : European Environment Agency. Retrieved from http://www.eea.europa.eu/publications/environmental-indicator-report-2014

- FAO (2012). Sustainable Diets and Biodiversity - Directions and solutions for policy, research and action. : Food and Agriculture Organization of the United Nations. Retrieved from http://www.fao.org/docrep/016/i3004e/i3004e00.htm

- Fiala, N. (2008). Measuring sustainability: Why the ecological footprint is bad economics and bad environmental science. Ecological Economics, 67(4), 519-525. Retrieved from http://linkinghub.elsevier.com/retrieve/pii/S0921800908003376 http://dx.doi.org/10.1016/j.ecolecon.2008.07.023

- Foley, J. A., Ramankutty, N., Brauman, K. A., Cassidy, E. S., Gerber, J. S., Johnston, M., . . Zaks, D. P. M. (2011). Solutions for a cultivated planet. Nature, 478(7369), 337-342. Retrieved from http://www.nature.com/doifinder/10.1038/nature10452 http://dx.doi.org/10.1038/nature10452

- Franz, J., \& Papyrakis, E. . Online calculators of ecological footprint: do they promote or dissuade sustainable behaviour. Sust. Dev, 19(6), 391-401. Retrieved from http://doi.wiley.com/10.1002/sd.446 http://dx.doi.org/10.1002/sd.446

- Glopolis (2017). Menu pro změnu. . Retrieved from https://www.eatresponsibly.eu/cs/

- Gonzales Fischer, C. \& Garnett, T., (2016). Plates, pyramids, planets. Developments in national healthy and sustainable dietary guidelines: A state of play assessment. : FAO and the University of Oxford.

- Hoekstra, A. Y. (2009). Human appropriation of natural capital: A comparison of ecological footprint and water footprint analysis. Ecological Economics, 68(7), 1963-1974. Retrieved from http://linkinghub.elsevier.com/retrieve/pii/S0921800908003078 http://dx.doi.org/10.1016/j.ecolecon.2008.06.021

- Hoekstra, A. Y. (2016). A critique on the water-scarcity weighted water footprint in LCA. Ecological Indicators, 66, 564-573. Retrieved from http://linkinghub.elsevier.com/retrieve/pii/S1470160X16300474 http://dx.doi.org/10.1016/j.ecolind.2016.02.026

- IFPRI (2016a). Global Food Policy Report: How We Feed the World is Unsustainable. Washington, DC.: International Food Policy Research Institute. Retrieved from http://www.ifpri.org/publication/2016-global-food-policy-report

- IFPRI (2016b). Global Nutrition Report 2016: From Promise to Impact: Ending Malnutrition by 2030. Washington, DC.: International Food Policy Research Institute. Retrieved from http://www.globalnutritionreport.org/the-report-2016/

- Janoušková, S., Moldan, B., \& Hák, T. (2017). Pět klíčvých indikátorů udržitelného rozvoje: nástroj pro vzdělávání a osvětu veřejnosti. Envigogika, 12(1), Retrieved 
from https://www.envigogika.cuni.cz/index.php/Envigogika/article/view/536 http://dx.doi.org/10.14712/18023061.536

- Kapitulčinová, D. (2017). „Udržitelná strava”: Představení konceptu a zohlednění v současných výživových doporučeních ve světě. Výživa a potraviny, 2017(3), 64-68.

- Leach, A. M., Galloway, J. N., Bleeker, A., Erisman, J. W., Kohn, R., \& Kitzes, J. (2012). A nitrogen footprint model to help consumers understand their role in nitrogen losses to the environment. Environmental Development, 1(1), 40-66. Retrieved from http://linkinghub.elsevier.com/retrieve/pii/S221146451100008X http://dx.doi.org/10.1016/j.envdev.2011.12.005

- Lukas, M., Palzkill, A., \& Liedtke, C. (2013) The nutritional footprint - an innovative management approach for the food sector. In C. A. Brebbia \& V. Popov (Eds.), Food and Environment II: The Quest for a Sustainable Future (Vol. 170). : WIT Press. Retrieved from http://www.witpress.com/books/978-1-84564-702-5

- Lukas, M., Rohn, H., Lettenmeier, M., Liedtke, C., \& Wiesen, K. (2016). The nutritional footprint - integrated methodology using environmental and health indicators to indicate potential for absolute reduction of natural resource use in the field of food and nutrition. Journal of Cleaner Production, 132, 161-170. Retrieved from http://linkinghub.elsevier.com/retrieve/pii/S0959652615001948 http://dx.doi.org/10.1016/j.jclepro.2015.02.070

- Machackova, M., Giertlova, A., \& Porubska, J. (2015). How to calculate nutrient content of foods - A guideline for food business operators. EuroFIR AISBL (Belgium), Institute of Agricultural Economics and Information (Czech Republic), National Agricultural and Food Centre, Food Research Institute (Slovak Republic). .

- Matějček, T., \& Bartoš, J. (2012). Environmentální gramotnost učitelů a studentů učitelství. Envigogika, 7(2), Retrieved from http://www.envigogika.cuni.cz/index.php/Envigogika/article/view/75 http://dx.doi.org/10.14712/18023061.75

- Merrigan, K., Griffin, T., Wilde, P., Robien, K., Goldberg, J., \& Dietz, W. (2015). Designing a sustainable diet. Science, 350(6257), 165-166. Retrieved from http://www.sciencemag.org/cgi/doi/10.1126/science.aab2031 http://dx.doi.org/10.1126/science.aab2031

- Pfister, S., Boulay, A., Berger, M., Hadjikakou, M., Motoshita, M., Hess, T., . . . Henderson, A. (2017). Understanding the LCA and ISO water footprint: A response to Hoekstra (2016) "A critique on the water-scarcity weighted water footprint in LCA". Ecological Indicators, 72, 352-359. Retrieved from http://linkinghub.elsevier.com/retrieve/pii/S1470160X16304599 http://dx.doi.org/10.1016/j.ecolind.2016.07.051

- Reisch, L., Eberle, U., \& Lorek, S. (2013). Sustainable food consumption: an overview of contemporary issues and policies. Sustainability: Science, Practice and Policy, 9(2), 7-25. Retrieved from https://www.tandfonline.com/doi/full/10.1080/15487733.2013.11908111 http://dx.doi.org/10.1080/15487733.2013.11908111

- Stern, N. H. (2006). Stern Review: The Economics of Climate Change. Paidos Iberica Ediciones S a: HM Treasury. http://www.webcitation.org/mainframe.php 
- Tukker, A., Goldbohm, R. Alexandra, de Koning, A., Verheijden, M., Kleijn, R., Wolf, O., . . Rueda-Cantuche, J. M. (2011). Environmental impacts of changes to healthier diets in Europe. Ecological Economics, 70(10), 1776-1788. Retrieved from http://linkinghub.elsevier.com/retrieve/pii/S092180091100190X http://dx.doi.org/10.1016/j.ecolecon.2011.05.001

- UNEP (2017). Sustainable Food Systems Programme. . Retrieved from http://web.unep.org/10yfp/programmes/sustainable-food-systems-programme

- Wackernagel, M., Monfreda, C., Schulz, N. B., Erb, K. H., \& Haberl, H. (2004). Calculating national and global ecological footprint time series: resolving conceptual challenges. Land use policy., 21(3), 271-278.

- Wiedmann, T., \& Barrett, J. (2010). A Review of the Ecological Footprint Indicator-Perceptions and Methods. Sustainability, 2(6), 1645-1693. Retrieved from http://www.mdpi.com/2071-1050/2/6/1645 http://dx.doi.org/10.3390/su2061645

- WHO (2016). Obesity and Overweight - Fact Sheet, World Health Organization. . Retrieved from http://www.who.int/mediacentre/factsheets/fs311/en/

- WHO (2017). United Nations Decade of Action on Nutrition. Retrieved from http://www.who.int/nutrition/decade-of-action/en 
Př́loha 1. Seznam expertů, se kterými proběhly osobní konzultace projektu Nutriční stopy v letech 2015 - 2017(dle termínu konzultace)

Jméno

Konzultace environmentálních indikátorů

Mgr. Miroslav Havránek

Doc. Ing. Jan Weinzettel, Ph.D.

Prof. RNDr. Bedřich Moldan, CSc.

Doc. Ing. Vladimír Kočí, Ph.D.

Mgr. Jan Kovanda, Ph.D.

Ing. Marie Tichá

Doc. PaedDr. Tomáš Hák, Ph.D.

Doc. RNDr. Svatava Janoušková. Ph.D.

Mgr. David Vačkář, Ph.D.

Ing. Zuzana Jelínková

prof. Ing. Jan Moudrý, CSc.

Ing. Radek Plch, Ph.D.

Stephan Pfister, Ph.D.

RNDr. Viktor Třebický, Ph.D.
Instituce

Termíny kon-

zultace

Konzultace projektu všeobecně (včetně výživy a vzdělávání)

Mgr. Miroslav Novák a Mgr. Jitka Buria- MŽP, Praha nová

Mgr. Iva Zvěřinová

Aurèle Destreé a Christine Doležalová (Maritz)

Ing. Miloslava Veselá

Prof. Ing. Jana Dostálová, CSc.

Mgr. Lenka Hebáková a RNDr. Ing. Tomáš Ratinger, Ph.D.

Ing. Hana Málková a Ing. Martin Pávek Karolína Silná a Veronika Bačová

Jitka Krbcová a Zuzana Jakobová

COŽP UK, Praha
COŽP UK, Praha
COŽP UK, Praha
VŠCHT, Praha
COŽP UK, Praha
UJEP/MT Konzult, Děčín
COŽP UK, Praha
COŽP UK, Praha
CzechGlobe/COŽP UK,
Praha
JČU, Č. Budějovice
JČU, Č. Budějovice
CzechGlobe, Č. Budějo-
vice
ETH Zurich, Curych
CI2, Praha

9. 6. 2016

9. 6.2016

14. 6. 2016

29. 7. 2016

9. 8.2016

15. 8.2016

24. 8. 2016

24. 8. 2016

6. 9.2016

14. 9.2016

14. 9.2016

14. 9. 2016

7. 11.2016

26. 1. 2017

22. 12. 2015

22. 12.2016

11. 10. 2017

9. 6. 2016

11. 8. 2016

16. 8.2016

9. 9.2016

5. 10.2016

7. 12.2016

6. 1.2017

Ekumenická akademie, Praha

TEREZA, Praha

26. 9.2017 